International Journal of Agriculture, Environment and Bioresearch

Vol. 5, No. 06; 2020

ISSN: $2456-8643$

\title{
LENGTH-WEIGHT RELATION AND CONDITION FACTOR NEMIPTERUS JAPONICUS IN SUNDA STRAIT
}

\author{
Nurilmi Achmad, Agus Suryahman, Muhammad Adam Asgar and Muhammad Yusuf \\ Aquaculture Department, Fishery Faculty, CokroaminotoUniversity of Makassar \\ https://doi.org/10.35410/IJAEB.2020.5574
}

\begin{abstract}
Kurisi (Nemipterus japonicus) is one of demersal fish economically important. Effort continued of kurisi to increase until it reaches the 3280 trip in 2010. This is what drives need for a management of fish resources kurisi that fit through the stock assessment based on aspects of Length-Weight relation and condition factor as the basic for fisheries resource management. Samples collected in April-August 2015. Kurisi in the waters of the Sunda Strait has a body length range 107-350 mm with a weight range of 13-252 g. Condition factor ranges between 0-1. Length-Weight relationships kurisi of males and females in the waters of the Sunda Strait showed allometric negative growth pattern $\mathrm{W}=0,00002 \mathrm{~L} 2,4844$ and $\mathrm{W}=0,0019 \mathrm{~L} 2,0144$. Kurisi females in this study had a high condition factor is the sampling time in April and June at 1.1241 and 1.0807. While the lowest condition factors on sampling in August is 0.9819. Kurisi males have the biggest factor conditions in April and the lowest month of May in the amount of 0.9292 and 0.6961 .
\end{abstract}

Keywords: length-weight relations, condition factors, kurisi, sunda strait.

\section{INTRODUCTION}

Kurisi fish (Nemipterus japonicus) is one of the economically important demersal fish that is widely distributed and caught in Indonesian waters and lives solitary in coastal waters with muddy or sandy water with a water depth of 5-80 m (Russell 1990). Efforts to catch curisi fish continue to increase until it reaches 3280 trips in 2010 and in India curisi fish is one of the demersal fish that has a high contribution to total fish landings by $15.34 \%$ (Swatipriyanka et al., 2012) so that this fish is classified as an economical fish. It is important because it is usually used by the community in daily trading in both fresh and processed form. Fishbase (2013), this fish spreads in almost all Indonesian waters (to the north covering the Gulf of Siam and the Philippines), South China Sea, Gulf of Thailand, Andaman Sea, Bay of Bengal, Laccadive Sea, Red Sea.

Several studies show that the intensity of the use of fish resources which continues to increase (intensively), with a little management effort has resulted in the loss of the diversity of fish resources and their habitat which is quite large so that the status of this fish utilization needs to be examined further.

Seeing the importance of fish resources encourages humans to exploit fish resources as much as possible. Thus, this fishing activity can affect the existence and change the status of curisi fish 
resource stocks, especially in the waters of the Sunda Strait so that these fish resources require an appropriate fisheries management so that the existence of fish stocks remains sustainable and sustainable.

This is what encourages the need to know the relationship between the length of weight and condition factors of the curri fish as the basis for the management of Kurisi fish resources with the boundaries of the fishing area of the Sunda Strait. curators in the waters of the Sunda Strait by paying attention to the preservation aspects of these resources in order to remain sustainable.

\section{RESEARCH METHOD}

\section{Location and Time}

This research was conducted from April 2019 to September 2019. The research location was in the Sunda Strait, while data collection was carried out at the Labuan Fish Landing Base (PPI), Pandeglang Regency, Banten Province. Primary data collection is in the form of measurements of the length and weight of curisi fish caught in the Sunda Strait and landed in PPI Labuan with one month interval sampling time.

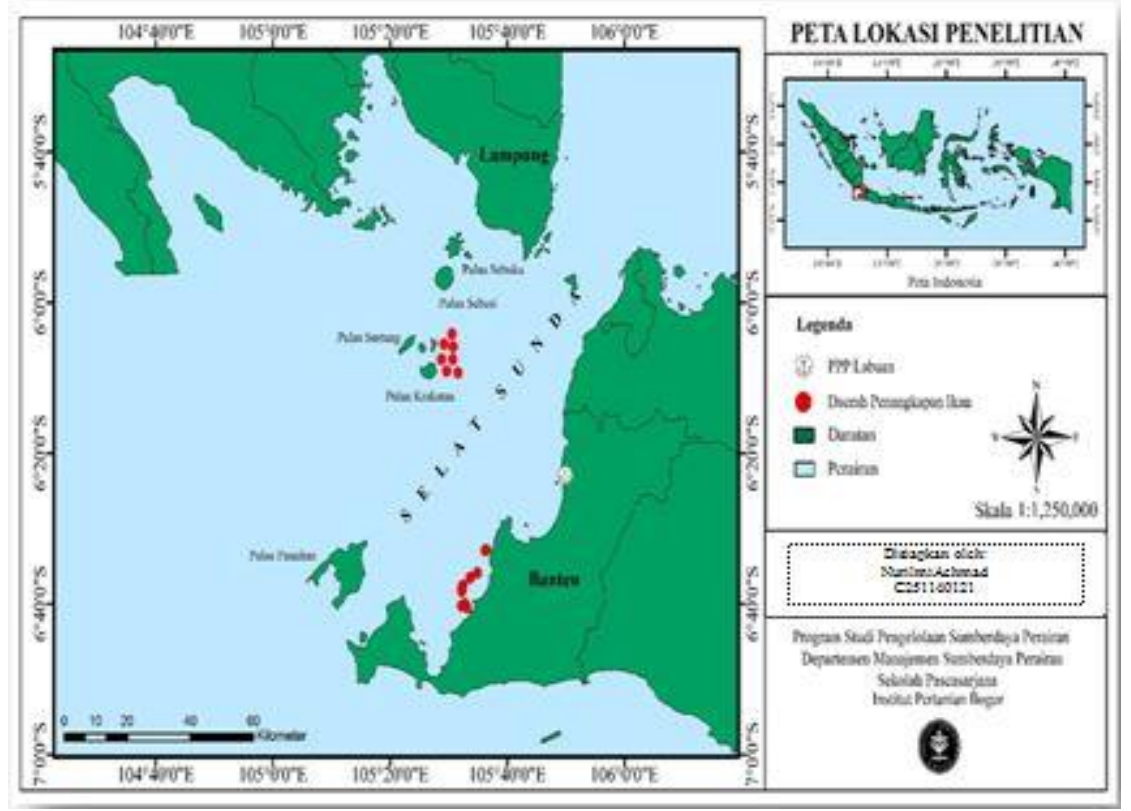

Figure 1. Map Of Fishing Ground Kurisi Fish (Nemipterus japonicus)

\section{Data Collection}

Primary data were obtained from sampling using the Layered Randomized Sampling Method (PCAB) on the types of curry fish that were only caught in the waters of the Sunda Strait and landed in PPI Labuan. The sample fish coating represents small, medium, and large fish for five 
Vol. 5, No. 06; 2020

ISSN: $2456-8643$

months with a time interval of once a month by calculating the total length and weight of the fish.

The total length is the length of the fish which is measured from the leading edge of the head to the end of the tail (Effendie 2002). This measurement is carried out using a $30 \mathrm{~cm}$ long ruler with the smallest scale of $1 \mathrm{~mm}$. Meanwhile, the weight of fish that is weighed is the total wet weight. Total wet weight is the total weight of fish body tissue and the water contained in it. In this case, a digital scale is used which has the smallest scale of 0.001 grams.

\section{Data Analysis}

The calculation of the long-weight relationship refers to the general formula Hile 1936 in Effendie 1979 with the formula:

$$
W=a L^{b}
$$

where: $\mathrm{W}=$ body weight, $\mathrm{L}=$ total length $(\mathrm{cm}), \mathrm{a} \& \mathrm{~b}=$ constant .

The closeness of the relationship between fish length and weight is shown by the correlation coefficient (r) obtained. The value of $r$ close to 1 shows that the relationship between the two variables is strong and there is a high correlation, but if $r$ approaches 0 , the relationship between the two is very weak or almost non-existent (Walpole 1992).

The relative condition factor is determined by the formula:

$$
\mathrm{Pl}_{\mathrm{n}}=\frac{\mathrm{Wb}}{\mathrm{aL}^{\mathrm{b}}} \text { atau } \mathrm{Pl}=\frac{\mathrm{Wb}}{\mathrm{W}^{*}}
$$

where: $\mathrm{Pln}=$ relative condition factor, $\mathrm{Wb}=$ observed body weight $(\mathrm{g}), \mathrm{aLb}=$ obtained from the length-weight relationship equation, $\mathrm{W}^{*}=$ estimated body weight $(\mathrm{g})$.

\section{RESULT AND DISCUSSION}

\section{Relationship Length Weight}

At the sampling location in the waters of the Sunda Strait, the Kurisi fish caught had a body length range of 107-330 mm. Male kurisi fish have a length ranging from 107-350 mm while female kurisi fish have a standard length ranging from 115-301 mm. Male and female curisi fish in the Sunda Strait have a negative allometric growth pattern. The long relationship of male and female curisi fish weight was $\mathrm{W}=0.00002 \mathrm{~L} 2.4844$ and $\mathrm{W}=0.0019 \mathrm{~L} 2.0144$, respectively. In the analysis of variance, it was found that the value of thit $>$ ttab, then the relationship between length and body weight was not significantly different at the 95\% confidence level. For male and female curisi fish, the coefficient of determination (R2) was $81.94 \%$ and $70.37 \%$. After the $t$ test was carried out with a 95\% confidence interval $(\alpha=0.05)$, it was found that male and female curisi fish in the waters of the Sunda Strait were allometric negatively. The same thing was obtained in Amine's (2012) study in Gulf that the curisi fish obtained had a negative allometric growth pattern with $a b$ value of 2.733 . According to Suwarni (2009), the growth pattern can be caused by the availability of food, the level of maturity of the gonads, and variations in body size of the sample fish. 
Kurisi fish are demersal fish and forage in coral waters so that it is possible that the coral conditions in the Sunda Strait waters have changed so that it affects the amount of food available. This resulted in a more dominant long growth due to allegations that the environment did not provide sufficient food for the growth of curisi fish.

The relationship between male and female curators caught in the waters of the Sunda Strait during the study can be seen in Figure 2 .

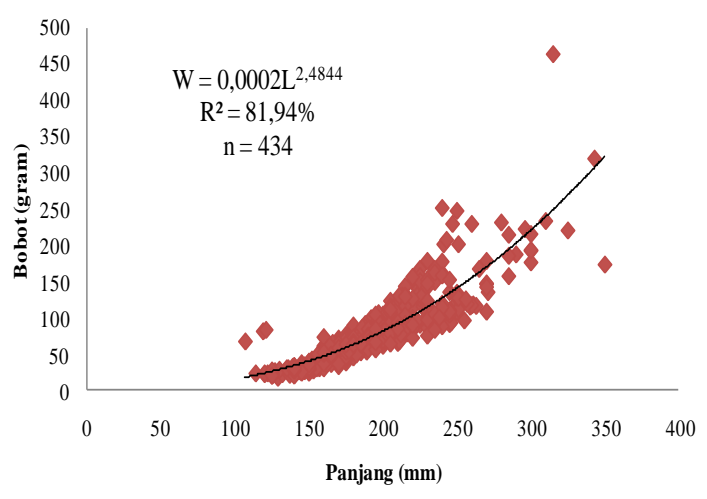

(a)

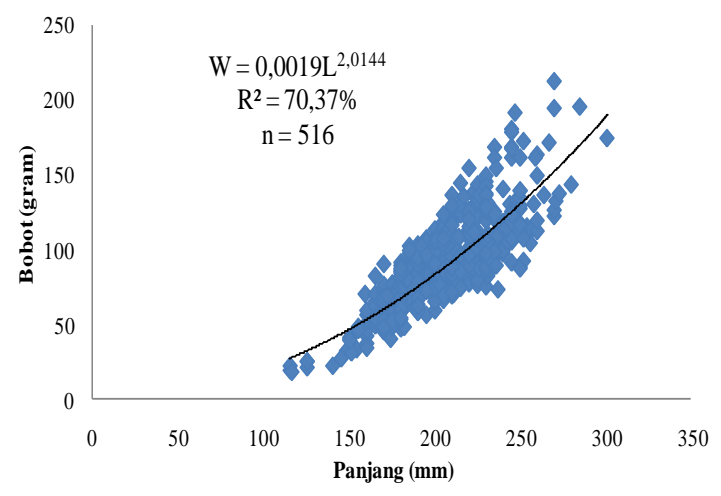

(b)

Figur 2.The long-weight relationship of male (a) and female (b) curisi fish in the waters of the Sunda Strait for each sampling

\section{Condition Factors}

Quantitative condition factors are needed to see the condition of the organism associated with several environmental factors that influence it at a certain time. Periodic changes in environmental factors will affect the condition of these organisms (Handayani, 2006).

Based on the results of the analysis of the curry fish during the study, it was found that the condition or the fertility of the fish, both male and female, was different every month. The conditions for male and female curators caught in the waters of the Sunda Strait during the study can be seen in Figure 3.

Quantitative condition factors are needed to see the condition of the organism associated with several environmental factors that influence it at a certain time. Periodic changes in environmental factors will affect the condition of these organisms (Handayani, 2006).

Based on the results of the analysis of the curry fish during the study, it was found that the condition or the fertility of the fish, both male and female, was different every month. The conditions for male and female curators caught in the waters of the Sunda Strait during the study can be seen in Figure 3. 
Vol. 5, No. 06; 2020

ISSN: $2456-8643$

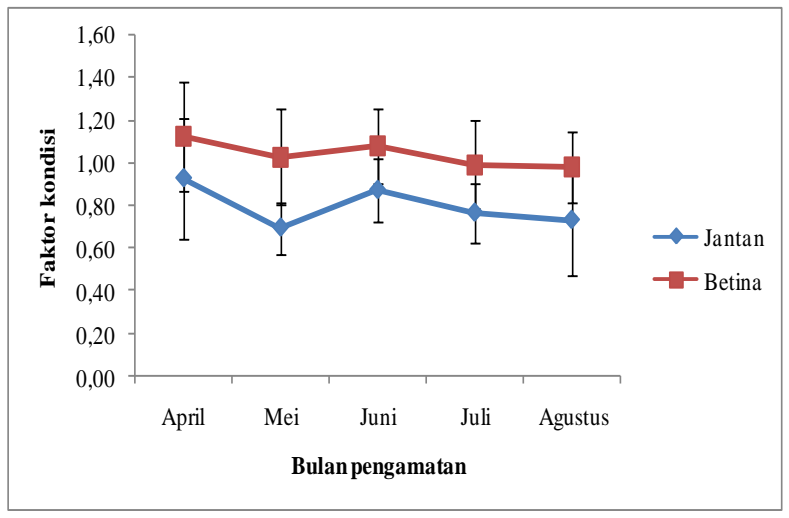

Figure 3. The condition factor of the average male and female curisi fish in the waters of the Sunda Strait for each sampling

Based on the results of the analysis of the curry fish during the study, it was found that the condition or the fertility of the fish, both male and female, was different every month. Male and female kurisi fish had the greatest condition factors in April, namely 0.9292 and 1.1241, while the lowest was in May (0.6961) for male curisi fish and August (0.9819) for female curisi fish. The value of curisi fish condition factors in this study is different from Nolaila's (2013) research, that the condition factors for female and male fish are in the range of 0.8614-1.1056 and 0.83081.0955 .

Condition factors can fluctuate. This situation is an indication of the spawning season for organisms, especially for females. The availability of food will affect the condition factor. In addition, an increase in the value of the condition factor is also thought to be because organisms that have undergone spawning will use the energy obtained for growth (Harahap and Djamali, 2005). When food is depleted, fish will tend to use up their fat reserves. The condition factor fluctuates in each month of observation. The condition factor in the lowest month is caused by the reduced availability of food or if the availability of food is sufficient at that time the decrease in the condition factor is due to the presence of fish that have experienced spawning.

The condition factor is related to the growth pattern. According to Lagler (1961), the variation in the value of this condition factor depends on food, age, species, sex, and the level of maturity of the gonads. The negative allometric growth pattern shows that the shedding of fish is not too big. The loss of this fish can be seen based on the condition of the curisi fish. Based on the results of the analysis, there are differences in condition factors between male and female curisi fish. The condition factor of female fish is higher than male fish, this means that female fish are more plump than male fish even though they have a negative allometric growth pattern or length growth is more dominant than weight.

\section{CONCLUSION}

From the observations made, it was found that the curisi fish in the waters of the Sunda Strait had a negative allometric growth pattern for both male and female fish species, with the 
equation obtained: $\mathrm{W}=0.00002 \mathrm{~L} 2.4844$ (male) and $\mathrm{W}=0.0019 \mathrm{~L} 2.0144$ (female) while the conditions for curisi fish ranged from 0.6961 to 0.9292 (males) and 0.9819-1.1241 (females).

\section{REFERENCES}

Amine A.M. 2012. Biology and assessment of the thread fin bream Nemipterus japonicusin Gulf of Suez, Egypt. J. Aquat. Biol. \& Fish., Vol. 16, No. 2: 47 - 57 (2012) ISSN 1110 -1131 Effendie MI. 1979. Biologi perikanan. Yogyakarta:Yayasan Pustaka Nusantara.

Fishbase. 2013. Nemipterus japonicus. [terhubung berkala]. http://www.fishbase.org/Summary/speciesSummary.htm. [17 Maret 2016].

Handayani, S. 2006. Studi Efisiensi Pemanfaatan Karbohidrat Pakan bagi Pertumbuhan Ikan Gurame (Osphronemus goramy Lac.)Sejalan dengan Perubahan Enzim Pencernaan dan Insulin. Desertasi. Institut pertanian

Bogor. Bogor.Harahap AP \& Bataragoa NE. 2008. Pola pertumbuhan dan faktor kondisi ikan kurisi (Aphareus rutilans Cuvier, 1830) di Perairan Laut Maluku. Jurnal Pacific. 1 (3):267291

Russell BC. 1990. FAO Species catologue, vol. 12. Nemipterid fishes of the world. (Threadfin breams, whiptall breams, monocle breams, dwarf monocle breams, and coral breams). Family Nemipteridae. An annotated and illustared catalogue of Nemipterid species know to date, FAO Fish Synop, 125 (12):149. Rome:FAO

Suwarni. 2009. Hubungan Panjang-Bobot Dan Faktor Kondisi Ikan Butana (Acanthurus Mata) Yang Tertangkap Di Sekitar Perairan Pantai Desa Mattiro Deceng, Kabupaten Pangkajene Kepulauan, Provinsi Sulawesi Selatan. [Jurnal] Ilmu Kelautan dan Perikanan ISSN 0853-4489 Vol 19 No 3. Universitas Hasanuddin, Makassar. 